GHANA JOURNAL OF DEPARTMENT OF HEALTH, PHYSICAL EDUCATION AND RECREATION, SPORTS AND DANCE (GJOHPERSD)

Volume 10, Year 2017

A JOURNAL OF THE DEPARTMENT OF HEALTH, PHYSICAL EDUCATION AND RECREATION (HPER)

UNIVERSITY OF CAPE COAST

GHANA, WEST AFRICA 


\title{
PREVALENCE OF OVERWEIGHT AND OBESITY AMONG SECONDARY SCHOOL STUDENTS IN ILORIN METROPOLIS KWARA STATE, NIGERIA.
}

\author{
${ }^{1}$ Adeoye, S.A., ${ }^{1}$ Dominic, O. L., ${ }^{2}$ Yusuf, A.N. \\ ${ }^{1}$ Department of Human Kinetics Education, Faculty of Education, \\ University of Ilorin, Ilorin, Kwara State, Nigeria. \\ ${ }^{2}$ Federal College of Education (Technical), Gusau, Zamfara State, \\ Nigeria \\ Corresponding Author: Adeoye, S.A \\ E-mail: sayhi2wale001@gmail.com / +234-7031562842
}

\begin{abstract}
Obesity became recognized in the classification of diseases 79 years ago (1948-2017). Since then, it has risen exponentially to become a global treat to health affecting different populations. The estimation of obesity prevalence cannot be overstressed. Therefore, this study investigated the prevalence of overweight and obesity among secondary school students in Ilorin Metropolis, Nigeria. A cross-sectional design was adopted for this study; the population for this study comprised all the secondary school students in the metropolis. Multistage sampling method comprising stratified; proportionate and simple random was used to select 1,569 participants for this study. Four research questions and hypotheses were answered and tested for this study. Frequency counts and percentage was used to answer the questions and independent sample t-test was used to test the hypotheses at 0.05 significance level. Anthropometric measures of Body Mass Index
\end{abstract}


Prevalence of Overweight and Obesity among Secondary School Students in Ilorin Metropolis Kwara State, Nigeria

(BMI) and Waist-Hip Ratio (WHR) conducted for classifications into overweight and obesity using percentile ranking. The standardized instruments for data collection were weight scale (BF9015B model) and inelastic tape rule that provides $100 \mathrm{~g}$ tension. All the measurements for this study were ISAK compliant. The four hypotheses were rejected and the percentage analysis of the data indicated that; $28.1 \%$ of the male students in the private schools were obese, $20.1 \%$ were obese in the public schools. In the female category, $23.0 \%$ were obese in the private schools while $21.8 \%$ were obese in the Public schools. The mean WHR for female in the private and public schools were 0.87 and 0.80 respectively. It was concluded that; overweight and obesity was prevalent in the schools but higher prevalent was recorded in the private schools. Regular participation in physical activity and routine assessment of overweight and obesity status of the students using BMI and WHR methods for monitoring and timely interventions were part of the recommendations.

Keywords: Overweight, Obesity, Participants, Body Mass Index and Waist-Hip Ratio 


\section{Introduction}

Obesity was first included in the international classification of diseases in 1948 (Ruth, Rusell \& Debbie, 2008) affecting all age groups and since then, it has risen to an epidemic proportion globally. Obesity is a condition in which excess fat accumulation in the body causes life threatening diseases. Childhood obesity is a condition where excess body fat negatively affects a child's health or well-being. As methods to determine body fat directly are difficult, the diagnosis of obesity is often based on estimation of body mass index ( $\underline{\mathrm{BMI}})$. It is a health hazard and a detriment to well-being which is reflected in the increased morbidity and mortality worldwide (Park, 2010).

Obesity is major risk factor in the history of other chronic and non- communicable diseases. Due to the rising prevalence of obesity in children and its many adverse health effects, it is now being recognized as a serious public health concern. Obesity is one of the core symptoms of cardiovascular disease and insulin resistance syndrome (Dominic, Onifade \& Lajide, 2010). The incidence of chronic diseases is escalating much more rapidly in developing countries than in industrialized countries.

There is strong evidence that childhood obesity is also becoming increasingly prevalent in developing countries and especially, among sedentary citizens (Monteiro, 2004), considering Nigeria as the most populous developing nation in Africa, it is logical to say that it is likely to have higher prevalence. Obesity has many health complications. The first problems to occur in these obese children are usually emotional or psychological. Kelishadi (2007) stated that, childhood obesity can also lead to serious conditions such as diabetes mellitus, high blood pressure, heart disease, sleep problems and cancer. Other disorders include liver disease, early puberty or menarche, eating disorders such as 
Prevalence of Overweight and Obesity among Secondary School Students in Ilorin Metropolis Kwara State, Nigeria

anorexia, bulimia, skin infections, asthma and other respiratory problems.

In the developed world, obesity and overweight is now the most common disease of childhood and adolescence (Reilly, 2006). Hill (2006) submitted that since 1980, the entire population, both in the United States of America and throughout the world has been increasing in weight, so also in Nigeria (Ojofeitimi \& Sabageh, 2013). The prevalence and increasing incidence also seem to cut across socio-economic status, level of education, physical activity level, age and the level of development of the population (Caterson \& Gill, 2002; Ward \& Maziak, 2006 Fontana, 2007; Shisslak \& Crago, 2006; Fouad, Rastam, Hippel, Powel, Downey \& Rowland, 2007; Senf,). In Africa and other developing countries, there have been acute transitions from traditional to a westernized or modern-world life-style. For instance, in Nigeria (West Africa), fast food outlets have increased in the last 10 years (Ojofeitimi \& Sabageh, 2013).

Working and non-working citizens of all age categories have deemed it fashionable and convenient to buy and eat at the fast food outlets rather than prepare their food and eat at home. Researchers have classified obesity into central and general (Ascaso, 2003; Okura, 2003; Brunner, Gutin \& Willis, 2007). The most widely used measures of total or general and abdominal obesity or adiposity are the body mass index (BMI) and waist circumference respectively. While abdominal obesity is recognized as a major risk factor for coronary heart diseases (CHD), waist circumference and waist hip ratio (WHR) are more strongly associated with metabolic risk factors, incident cardiovascular disease (CVD) events and deaths (Heitmann, 2004;Fouad, 2006;).

According to Senf (2006), there is an increasing prevalence of weight-related diseases in children. Excess body adiposity is a major component of Metabolic Syndrome (MS), a consortium of 
diseases which have been traced to later lead to type 2 diabetes, heart diseases and cerebro-vascular accident, if not properly controlled and treated (Kaslimal, 2006;Bakker, 2007;). MS is a cluster of health threatening and life-style related conditions.

According to Bakker, Gansevoort and de Xeeuw (2007), the criterion used to define MS are, increased waist circumference, increased triglycerides, decreased high density lipoprotein (HDL), cholesterol, increased blood pressure and increased plasma glucose. Anyone who has three or more of these criteria is diagnosed as having metabolic syndrome. Among children, the epidemic of childhood inactivity and consequent obesity appear to be fuelled by several factors including societal, cultural, industrial, financial, environmental and family factors. Park (2010) asserted that parental obesity, low economic status, lack of regular bodily activity and early maturation were some of the major factors that predispose to overweight and obesity in childhood, findings and research reports indicated increasing prevalence of overweight and obesity to be independent of socio-economic status (Corvalan, 2007; Fouad et al. 2006; McCarthy, 2005).

Ogden and Carroll (2007) reported significant positive association between size at birth, infant, early and later childhood growth and adult body composition. They found increased BMI in infancy and later childhood to be positively associated with four adult body composition measures of Body BMI, percent body fat, abdominal circumference and fat-free mass. Indeed overweight and obese children and adolescents have been known to shun physical activities, are socially inept, lazy and possess negative self-image. It has also been linked with breathing problems (CDC-NCHS, 2007). Ochs-Balcom (2006) reported significant inverse relationship between abdominal adiposity and pulmonary function.

Obesity affects the quality of life and increases health care costs (Bowman, 2006; Journal of America Medical Association, 
Prevalence of Overweight and Obesity among Secondary School Students in Ilorin Metropolis Kwara State, Nigeria

2006). Anthropometric measures of relative fatness are inexpensive and easy to use. The indirect methods of estimating body composition include measuring Body mass index (BMI), waist circumference, hip circumference and waist hip ratio (WHR). According to the Council on Sports Medicine and Fitness and Council on School Health (2006), BMI tends to correlate well with more precise measures of adiposity. This implies that BMI estimation is adequate for determination of central obesity. International Obesity Task Force (IOTF) BMI cutoff points for children was used to define overweight and obesity. These ageand gender-specific cut off points were derived from a large international sample with regression techniques, by passing a line through the adult cutoff points at 18 years.

Participants with BMI values corresponding to an adult BMI of $<25 \mathrm{~kg} / \mathrm{m} 2$ were classified as normal weight, participants with BMI values corresponding to an adult BMI of 25 to 29.9 $\mathrm{kg} / \mathrm{m} 2$ were classified as overweight and participants with BMI values corresponding to an adult BMI of $30 \mathrm{~kg} / \mathrm{m} 2$ were classified as obese. Centers for Disease Control (C.D.C, 2000) sets the rankings at $\leq 5$ th percentile as underweight, 5 th -85 th percentile as normal weight, 85 th- 95 th percentile as overweight and over 95th percentile as being obese for adolescents. However, the National Health and Nutrition Examination Survey (2012) classification for waist hip ratio was adopted for this study. The table below indicates the rankings:

\begin{tabular}{|l|l|l|l|l|}
\hline Gender & Excellent & Good & Average & At Risk \\
\hline Male & $<0.85$ & $<0.85-$ & $<0.90-0.95$ & $\geq 0.95$ \\
& & 0.89 & & \\
\hline Female & $<0.75$ & $<0.75-$ & $<0.80-0.86$ & $\geq 0.86$ \\
& & 0.79 & & \\
\hline
\end{tabular}

Source: NHANES (2012). 
Many countries in Africa including Nigeria are going through economic, physical activity and nutritional transition. The nutrition transition is associated with a change in dietary habits, decreasing physical activity and rising prevalence of obesity. Overweight and obesity are major risk factors for a number of chronic diseases, including diabetes, cardiovascular diseases and cancer. Obesity in children and adolescents is gradually becoming a major public health problem in many developing countries, including Nigeria. One-half of obese school children become obese adults, this implies that, obese child has a higher chance of becoming obese adult. The World Health Organisation (2016) reported that; more than 1.9 billion adults aged 18 years and older were overweight. Of these, over 650 million adults were obese.

WHO (2016) further reported that, 39\% of adults aged 18 years and over (39\% of men and $40 \%$ of women) were overweight. Generally, about $13 \%$ of the world's adult population (11\% of men and $15 \%$ of women) was obese in 2016 . The worldwide prevalence of obesity nearly tripled between 1975 and 2016. The prevalence of overweight and obesity among children and adolescents aged 519 has risen exponentially from just $4 \%$ in 1975 to over $18 \%$ in 2016. The rise has occurred similarly among both boys and girls: in $201618 \%$ of girls and $19 \%$ of boys were overweight. While just less than $1 \%$ of children and adolescents aged 5-19 were obese in 1975 , more 124 million children and adolescents $(6 \%$ of girls and $8 \%$ of boys) were obese in 2016.

The World health Organisation also reported that in 2016 (W.H.O, 2016), an estimated 41 million children under the age of 5 years were overweight or obese. Overweight and obesity which was once considered a high-income country burden, overweight and obesity are now on the rise in low- and middle-income countries, particularly in urban settings. In Africa, the number of 
Prevalence of Overweight and Obesity among Secondary School Students in Ilorin Metropolis Kwara State, Nigeria

overweight children under 5 has increased by nearly 50 per cent since 2000. Over 340 million children and adolescents aged 5-19 were overweight or obese in 2016. It could be deduced from the report that obesity prevalence has continued to rise both in adult and childhood over the years. Lokuruka (2013) asserted that literature on obesity syndrome status in Africa is still very scanty.

Sabageh and Ojofeitimi (2013) conducted a study among secondary students and found that; $44 \%$ had normal weight, $1.2 \%$ were overweight, $1.2 \%$ obese and had mean waist -hip ratio of 0.85 for males and 0.82 for females. Akinpelu, Oyewole and Oritogun (2008) found that the prevalence rate for female adolescents was 2.7\%. Another study conducted by Ansa, Odigwe and Anah (2001) reported that $4 \%$ females were obese while $3 \%$ males respectively. A study conducted by Abah et.al (2012) reported 5.71\% as overweight and $0.9 \%$ obese among students in the Public secondary schools compared to $11.5 \%$ as overweight and $1 \%$ among their private counterparts. Another study conducted by Ekpenyong and Akpan (2013) found that obesity was more prevalent in girls living in the urban areas and attending private school than their public colleagues. Similarly, Ojofeitimi and Sabageh (2013) asserted that studies on the prevalence of childhood overweight and obesity and their association with chronic diseases in adulthood are still under appreciated in Nigeria.

Furthermore, Mustapha and Sanusi (2013) affirmed that there is no current national figure on adolescent overweight and obesity in Nigeria. The assertions from these authors imply that there is need to conduct empirical studies in different countries of Africa to generate national data for adequate information and subsequent planning. Therefore, the significance of estimating prevalence of childhood obesity cannot be overemphasized. 


\section{Objectives of the Study}

The objective of this study was to investigate the prevalence of overweight and obesity among secondary school students in Ilorin metropolis using BMI and WHR estimation.

\section{Research Questions}

The following questions were raised to provide focus for this study:

1. What is the prevalence rate of obesity among male students in private secondary schools in Ilorin Metropolis?

2. What is the prevalence rate of obesity among male students in public secondary schools in Ilorin Metropolis?

3. What is the prevalence rate of obesity among female students in private secondary schools in Ilorin Metropolis?

4. What is the prevalence rate of obesity among female students in public secondary schools in Ilorin Metropolis?

\section{Hypotheses}

The following null hypotheses were formulated to guide this study;

1. There is no significant difference between Body Mass index (BMI) of male students in the Private and Public Secondary Schools in Ilorin Metropolis.

2. There is no significant difference between Body Mass index of female students in the Private and Public Secondary Schools in Ilorin Metropolis.

3. There is no significant difference between the Waist to hip ratio (WHR) of female students in the Private and Public Secondary Schools in Ilorin Metropolis. 
Prevalence of Overweight and Obesity among Secondary School Students in Ilorin Metropolis Kwara State, Nigeria

4. There is no significant difference between the waist - to hip ratio of male students in the Private and Public Secondary Schools in Ilorin Metropolis.

\section{Methods and Materials}

Cross-sectional anthropometric data were collected for this study. The study population comprised all the students in the public and private secondary schools in Ilorin Metropolis. A multistage sampling technique was employed for this study; there are three local governments in the metropolis (South, East and West), stratified sampling technique was used to classify the students into Public and Private schools. There were 82 schools in the south, 54 in the West and 56 in the East. Proportionate sampling technique was also used to select $10 \%$ of the total schools in each stratum and finally, simple random sampling technique of ballot dip technique was employed to select 639 students in Ilorin south, 456 students in Ilorin west and 501 students in Ilorin east. The sample size for this study was 1,569.

The data for this study was collected using standardized and calibrated instruments. The weight of the participants was measured using weight scale (Camry Model BF9015B). The Participants were weighed to the nearest $0.1 \mathrm{~kg}$ under light clothing without their shoes, wrist watches and caps. Stadiometre was used to measure the height to the nearest $0.1 \mathrm{~cm}$ for estimation of Body Mass Index (BMI) and inextensible tape rule that provides $100 \mathrm{~g}$ tension calibrated to $150 \mathrm{~cm}$ was used to measure the Waist Circumference (WC) and Hip Circumference (HC) for estimation of WHR of the study participants. All the measurements for this study were ISAK (2006) compliant. BMI was calculated as weight (kg) divided by height $(\mathrm{m})$ squared. The inextensible tape was used to measure the circumference of the buttocks.

Waist circumference was measured at a level midway between the lowest rib and the crista iliac superior. The 
measurement was carried out at the end of a normal expiration while the subject stood upright with feet together an arms hanging freely at the sides. Hip circumference was measured at the maximum point below the waist, without compressing the skin. WHR was calculated by dividing the waist measurement by the hip measurement.

The demographic data was analyzed with frequency, percentile ranking and percentage, while, inferential statistics of independent sample t-test was used to test the null hypotheses formulated. WC and HC ratio was calculated to obtain WHR of the participants. The Statistical Package for Social Science (SPSS 20.0 version) was used for computation of the data. The significance was tested at 0.05 alpha.

\section{Results and Discussion of Findings}

Table 2: Showing Frequency Distribution of the Male Participants in the Private and Public Secondary Schools in Ilorin Metropolis by Age.

\begin{tabular}{ccclc}
\hline Age & $\begin{array}{c}\text { Frequency } \\
\text { Private }\end{array}$ & Percentage & $\begin{array}{l}\text { Frequency } \\
\text { Percentage } \\
\text { Public }\end{array}$ & \\
\hline $10-12 \mathrm{yrs}$ & 219 & 42.5 & 194 & 42.7 \\
$13-15 \mathrm{yrs}$ & 168 & 32.6 & 160 & 35.2 \\
$16-18 \mathrm{yrs}$ & 96 & 18.7 & 66 & 14.6 \\
$19-21 \mathrm{yrs}$ & 19 & $2.5 \%$ & 25 & 5.5 \\
$22-$ & 13 & $3.7 \%$ & 9 & 2.0 \\
$24 \mathrm{yrs}$ & & & & \\
\hline Total & $\mathbf{5 1 5}$ & $\mathbf{1 0 0}$ & $\mathbf{4 5 4}$ & $\mathbf{1 0 0}$ \\
\hline
\end{tabular}

Table 2 shows that the majority $219(42.5 \%)$ of the participants in the private schools belonged to the age category of 
Prevalence of Overweight and Obesity among Secondary School Students in Ilorin Metropolis Kwara State, Nigeria

10-12yrs and a similar trend was observed in among the participants in the public schools with 194(42.7\%) being the majority (10-12yrs old).

Table 3: Showing Frequency Distribution of the Female Participants in the Private and Public Secondary Schools in Ilorin Metropolis by Age.

\begin{tabular}{ccccc}
\hline Age & $\begin{array}{c}\text { Frequency } \\
\text { Private }\end{array}$ & Percentage & $\begin{array}{c}\text { Frequency } \\
\text { Public }\end{array}$ & Percentage \\
\hline $\begin{array}{c}10- \\
12 \mathrm{yrs} \\
13-\end{array}$ & 105 & 37.4 & 109 & 31.5 \\
$\begin{array}{c}15 \mathrm{yrs} \\
16-\end{array}$ & 106 & 37.7 & 134 & 38.7 \\
$\begin{array}{c}18 \mathrm{yrs} \\
19-\end{array}$ & 46 & 16.4 & 74 & 21.4 \\
$\begin{array}{c}11 \mathrm{yrs} \\
22-\end{array}$ & 6 & 6.4 & 28 & 8.1 \\
$24 \mathrm{yrs}$ & 18 & 2.1 & 1 & 0.3 \\
\hline Total & $\mathbf{2 8 1}$ & $\mathbf{1 0 0}$ & $\mathbf{3 4 6}$ & $\mathbf{1 0 0}$ \\
\hline
\end{tabular}

Table 3 shows that the majority $106(37.7 \%)$ of the participants were between the age range of 13-15yrs and closely followed by $10-12 \mathrm{yrs}$ old 106 (37.4\%). However, 10-12yrs old $105(37.4 \%)$ in the public category formed the majority of the participants $109(31.5 \%)$. This revealed that in the female category, the public students were relatively older. 
Adeoye et al

Table 4: Showing Frequency Distribution and Percentile Rank of the Body Mass Index of the Male Participants in the Public Secondary Schools in Ilorin Metropolis.

\begin{tabular}{cccc}
\hline $\begin{array}{c}\text { Body Mass } \\
\text { Index }\end{array}$ & Frequency & $\begin{array}{c}\text { Percentage } \\
\mathbf{( \% )}\end{array}$ & $\begin{array}{c}\text { Percentile } \\
\text { Range }\end{array}$ \\
\hline 14.2 & 5 & 1.1 & $\leq 5^{\text {th }}$ \\
15.4 & 14 & 3.1 & $\leq 5^{\text {th }}$ \\
16.7 & 20 & 4.4 & $5^{\text {th }}-85^{\text {th }}$ \\
17.2 & 35 & 7.8 & $5^{\text {th }}-85^{\text {th }}$ \\
18.6 & 170 & 37.4 & $5^{\text {th }}-85^{\text {th }}$ \\
19.6 & 4 & 0.9 & $5^{\text {th }}-85^{\text {th }}$ \\
20.1 & 78 & 17.2 & $85^{\text {th }}-85^{\text {th }}$ \\
21.5 & 54 & 11.9 & $85^{\text {th }}-95^{\text {th }}$ \\
22.3 & 36 & 7.9 & $85^{\text {th }}-95^{\text {th }}$ \\
23.9 & 9 & 2.0 & $85^{\text {th }}-95^{\text {th }}$ \\
24.2 & 8 & 1.8 & $95^{\text {th }}$ above \\
25.7 & 7 & 1.5 & $95^{\text {th }}$ above \\
26.8 & 3 & 0.7 & $95^{\text {th }}$ above \\
27.1 & 7 & 1.5 & $95^{\text {th }}$ above \\
30.2 & 2 & 0.4 & $95^{\text {th }}$ above \\
31.3 & 2 & 0.4 & $95^{\text {th }}$ above \\
Total & $\mathbf{4 5 4}$ & $\mathbf{1 0 0}$ & \\
\hline
\end{tabular}

Table 4 revealed that $19(4.2 \%)$ among the male participants in the public secondary school were underweight $\left(\leq 5^{\text {th }}\right.$ percentile), $225(49.6 \%)$ had healthy weight $\left(5^{\text {th }}-85^{\text {th }}\right.$ percentile), $82(18.1 \%)$ among the participant were overweight and $128(28.1 \%)$ were obese among the participants respectively. 
Prevalence of Overweight and Obesity among Secondary School Students in Ilorin Metropolis Kwara State, Nigeria

Table 5: Showing Frequency Distribution and Percentile Ranking of the Body Mass Index of the Male Participants in the Private Secondary Schools in Ilorin Metropolis.

\begin{tabular}{llll}
\hline $\begin{array}{l}\text { Body Mass } \\
\text { Index }\end{array}$ & Frequency & $\begin{array}{l}\text { Percentage } \\
(\%)\end{array}$ & $\begin{array}{l}\text { Percentile } \\
\text { Rank }\end{array}$ \\
\hline 13.0 & 1 & 0.2 & $\leq 5^{\text {th }}$ \\
15.4 & 9 & 1.7 & $\leq 5^{\text {th }}$ \\
16.6 & 32 & 6.2 & $5^{\text {th }} 85^{\text {th }}$ \\
17.8 & 53 & 10.3 & $5^{\text {th }} 85^{\text {th }}$ \\
18.6 & 102 & 19.4 & $5^{\text {th }} 85^{\text {th }}$ \\
19.7 & 100 & 19.8 & $85^{\text {th }}-95^{\text {th }}$ \\
20.5 & 61 & 11.4 & $85^{\text {th }}-95^{\text {th }}$ \\
21.4 & 56 & 10.9 & $85^{\text {th }}-95^{\text {th }}$ \\
22.8 & 29 & 5.6 & $\geq 95^{\text {th }}$ \\
23.7 & 31 & 6.0 & $\geq 95^{\text {th }}$ \\
24.9 & 2 & 0.4 & $\geq 95^{\text {th }}$ \\
25.8 & 11 & 2.1 & $\geq 95^{\text {th }}$ \\
26.4 & 9 & 1.7 & $\geq 95^{\text {th }}$ \\
27.0 & 4 & 0.8 & $\geq 95^{\text {th }}$ \\
29.3 & 4 & 1.3 & $\geq 95^{\text {th }}$ \\
30.8 & 1 & 0.2 & $\geq 95^{\text {th }}$ \\
31.1 & 4 & 0.8 & $\geq 95^{\text {th }}$ \\
35.3 & 6 & 1.2 & $\geq 95^{\text {th }}$ \\
Total & $\mathbf{5 1 5}$ & $\mathbf{1 0 0}$ & \\
\hline
\end{tabular}

Table 5 revealed that $10(1.9 \%)$ were underweight(less than $5^{\text {th }}$ percentile), $187(35.9 \%)$ of the participants had healthy weight $\left(5^{\text {th }}\right.$ $-85^{\text {th }}$ percentile), 217 (42.1\%) were overweight and $101(20.1 \%)$ were obese $\left(\geq 95^{\text {th }}\right.$ percentile) among the male participant in the private schools.

Table 6: Showing Frequency Distribution of Waist-to Hip Ratio (WHR) of the Male Participants in the Private and Public Secondary Schools in Ilorin Metropolis. 
Public

Adeoye et al

Private

\begin{tabular}{cccccc}
\hline $\begin{array}{c}\text { WH } \\
\mathbf{R}\end{array}$ & $\begin{array}{c}\text { Frequenc } \\
\mathbf{y}\end{array}$ & $\begin{array}{c}\text { Percentag } \\
\mathbf{e}(\mathbf{\%})\end{array}$ & $\begin{array}{c}\text { WH } \\
\mathbf{R}\end{array}$ & $\begin{array}{c}\text { Frequenc } \\
\mathbf{y}\end{array}$ & $\begin{array}{c}\text { Percentag } \\
\mathbf{e}(\boldsymbol{\%})\end{array}$ \\
\hline 0.5 & 5 & 1.1 & 0.50 & 5 & 0.1 \\
0.6 & 9 & 2.0 & 0.60 & 9 & 1.7 \\
0.65 & 1 & 0.2 & 0.65 & 1 & 0.2 \\
0.66 & 2 & 0.8 & 0.66 & 1 & 0.2 \\
0.67 & 6 & 1.2 & 0.67 & 1 & 0.2 \\
0.70 & 2 & 0.4 & 0.70 & 46 & 8.9 \\
0.76 & 2 & 0.4 & 0.71 & 2 & 0.4 \\
0.77 & 6 & 1.2 & 0.72 & 2 & 0.4 \\
0.78 & 5 & 1.1 & 0.73 & 1 & 0.2 \\
0.79 & 2 & 0.4 & 0.74 & 1 & 0.2 \\
0.80 & 57 & 12.6 & 0.75 & 1 & 0.2 \\
0.82 & 31 & 6.8 & 0.76 & 1 & 0.2 \\
0.83 & 11 & 2.4 & 0.77 & 11 & 2.1 \\
0.84 & 12 & 2.6 & 0.78 & 10 & 1.9 \\
0.85 & 32 & 7.0 & 0.79 & 9 & 1.7 \\
0.86 & 51 & 11.2 & 0.80 & 39 & 7.6 \\
0.87 & 24 & 5.3 & 0.81 & 7 & 1.4 \\
0.90 & 49 & 10.8 & 0.84 & 4 & 0.8 \\
0.91 & 62 & 13.7 & 0.85 & 23 & 4.5 \\
0.93 & 14 & 3.1 & 0.86 & 24 & 4.7 \\
0.93 & 53 & 11.7 & 0.87 & 31 & 6.7 \\
0.94 & 12 & 2.7 & 0.88 & 44 & 8.5 \\
0.95 & 4 & 0.9 & 0.89 & 39 & 7.7 \\
0.96 & 2 & 0.4 & 0.90 & 109 & 22.1 \\
& & & 0.91 & 24 & 4.7 \\
& & & 0.92 & 10 & 1.9 \\
& & & 0.93 & 11 & 2.1 \\
& & & 0.94 & 4 & 0.8 \\
& & & 0.99 & 5 & 0.1 \\
& & & 1.0 & 40 & 7.8 \\
& & $\mathbf{1 0 0}$ & $\mathbf{T o t a l}$ & $\mathbf{5 1 5}$ & $\mathbf{1 0 0}$ \\
\hline
\end{tabular}

Table 10 indicates the percentage analysis of waist-hip ratio (WHR) classification of the male participants in the public and 
Prevalence of Overweight and Obesity among Secondary School Students in Ilorin Metropolis Kwara State, Nigeria

private schools. Among the participants in the public, 151(33.2\%) were underweight (WHR of $\leq 0.85), 107$ (23.5\%) had healthy WHR (0.85-0.89), 194(42.9\%) of the participants were at borderline $(0.9-0.95) 2(0.4 \%)$ were at risk of abdominal fat $(\geq 0.95)$ according to $\mathrm{CDC}$ classification. Also, the percentage analysis for the male participants in the private school revealed that $151(28.4 \%)$ were underweight $(\leq 0.85$ WHR $), 161(32.1 \%)$ had healthy WHR (0.85-0.89), 158 (36.1\%) were at borderline and 45 (7.9\%) of the participants were at risk of abdominal fat (WHR $\geq$ $0.95)$.

Table 7: Showing Frequency Distribution and Percentile Rank of the Body Mass Index of the Female Participants in the Private and Public Secondary Schools in Ilorin Metropolis.

Public

Private

\begin{tabular}{cccccccc}
\hline $\begin{array}{c}\text { B } \\
\text { MI }\end{array}$ & $\begin{array}{l}\text { Frequ } \\
\text { ency }\end{array}$ & $\begin{array}{c}\text { Percen } \\
\text { tage }\end{array}$ & $\begin{array}{c}\text { Perce } \\
\text { ntile } \\
\text { Rank }\end{array}$ & $\begin{array}{c}\text { B } \\
\text { MI }\end{array}$ & $\begin{array}{c}\text { Frequ } \\
\text { ency }\end{array}$ & $\begin{array}{c}\text { Percen } \\
\text { tage }\end{array}$ & $\begin{array}{c}\text { Perce } \\
\text { ntile } \\
\text { Rank }\end{array}$ \\
\hline $\begin{array}{c}14 . \\
0\end{array}$ & 12 & 3.5 & $\leq 5^{\text {th }}$ & $\begin{array}{c}14 . \\
8\end{array}$ & 3 & 0.9 & $\leq 5^{\text {th }}$ \\
14. & 1 & 0.3 & $\leq 5^{\text {th }}$ & $\begin{array}{c}15 . \\
8\end{array}$ & 9 & 2.6 & $\leq 5^{\text {th }}$ \\
2 & & & & 8 & & & \\
14. & 5 & 1.4 & $\leq 5^{\text {th }}$ & $\begin{array}{c}16 . \\
5\end{array}$ & 45 & 13.0 & $5^{\text {th }}-$ \\
5 & & & & 5 & & & $85^{\text {th }}$ \\
15. & 17 & 4.9 & $\leq 5^{\text {th }}$ & 17. & 46 & 13.3 & $5^{\text {th }}-$ \\
6 & & & & 4 & & & $85^{\text {th }}$ \\
16. & 51 & 14.7 & $5^{\text {th }}-$ & 18. & 44 & 12.3 & $5^{\text {th }}-$ \\
4 & & & $85^{\text {th }}$ & 7 & & & $85^{\text {th }}$ \\
17. & 35 & 10.1 & $5^{\text {th }}-$ & 19. & 68 & 19.6 & $85^{\text {th }}-$ \\
7 & & & $85^{\text {th }}$ & 6 & & & $95^{\text {th }}$ \\
18. & 64 & 18.5 & $5^{\text {th }}-$ & 20. & 31 & 9.0 & $85^{\text {th }}-$ \\
4 & & & $85^{\text {th }}$ & 3 & & & $95^{\text {th }}$ \\
19. & 43 & 12.2 & $85^{\text {th }}-$ & 21. & 24 & 6.9 & $\geq 95^{\text {th }}$ \\
6 & & & $95^{\text {th }}$ & 7 & & &
\end{tabular}




\begin{tabular}{|c|c|c|c|c|c|c|c|}
\hline $\begin{array}{c}20 . \\
5\end{array}$ & 46 & 13.3 & $\begin{array}{l}85^{\text {th }}- \\
95^{\text {th }}\end{array}$ & $\begin{array}{c}22 . \\
5\end{array}$ & 12 & 3.8 & $\begin{array}{c}\text { Adeoye et al } \\
\geq 95^{\text {th }}\end{array}$ \\
\hline $\begin{array}{c}21 . \\
3\end{array}$ & 15 & 4.3 & $\geq 95^{\text {th }}$ & $\begin{array}{c}23 . \\
4\end{array}$ & 36 & 10.4 & $\geq 95^{\text {th }}$ \\
\hline $\begin{array}{c}22 . \\
4\end{array}$ & 19 & 5.5 & $\geq 95^{\text {th }}$ & $\begin{array}{c}24 . \\
8\end{array}$ & 4 & 1.2 & $\geq 95^{\text {th }}$ \\
\hline $\begin{array}{c}23 . \\
7\end{array}$ & 9 & 2.8 & $\geq 95^{\text {th }}$ & $\begin{array}{c}25 . \\
1\end{array}$ & 10 & 2.9 & $\geq 95^{\text {th }}$ \\
\hline $\begin{array}{c}24 . \\
4\end{array}$ & 4 & 1.2 & $\geq 95^{\text {th }}$ & $\begin{array}{c}26 . \\
3\end{array}$ & 5 & 1.4 & $\geq 95^{\text {th }}$ \\
\hline $\begin{array}{c}25 . \\
6\end{array}$ & 7 & 2.0 & $\geq 95^{\text {th }}$ & $\begin{array}{c}28 . \\
5\end{array}$ & 4 & 1.2 & $\geq 95^{\text {th }}$ \\
\hline $\begin{array}{c}26 . \\
2\end{array}$ & 9 & 2.6 & $\geq 95^{\text {th }}$ & $\begin{array}{c}29 . \\
6\end{array}$ & 2 & 0.6 & $\geq 95^{\text {th }}$ \\
\hline $\begin{array}{c}28 . \\
6\end{array}$ & 3 & 0.9 & $\geq 95^{\text {th }}$ & $\begin{array}{c}30 . \\
5\end{array}$ & 2 & 0.6 & $\geq 95^{\text {th }}$ \\
\hline $\begin{array}{c}29 . \\
4\end{array}$ & 3 & 0.9 & $\geq 95^{\text {th }}$ & $\begin{array}{c}30 . \\
7\end{array}$ & 1 & 0.3 & $\geq 95^{\text {th }}$ \\
\hline $\begin{array}{c}30 . \\
3\end{array}$ & 3 & 0.9 & $\geq 95^{\text {th }}$ & & & & \\
\hline $\begin{array}{l}\text { To } \\
\text { tal }\end{array}$ & 346 & 100 & & $\begin{array}{l}\text { To } \\
\text { tal }\end{array}$ & 281 & 100 & \\
\hline
\end{tabular}

Table 7 indicates that $35(10.1 \%)$ were underweight $\left(\leq 5^{\text {th }}\right.$ percentile $), 150(43.3 \%)$ had healthy weight $\left(5^{\text {th }}-85^{\text {th }}\right.$ percentile $)$, $89(25.5 \%)$ were overweight $\left(85^{\text {th }}-95^{\text {th }}\right.$ percentile $)$ and $72(21.8 \%)$ were obese among the female participants in the public schools. The percentage analysis also in table 11 reveals that $11(3.5 \%)$ were underweight $\left(\leq 5^{\text {th }}\right.$ percentile), 135 (44.9\%) had healthy weight $\left(5^{\text {th }}-85^{\text {th }}\right.$ percentile $), 99(28.6 \%)$ were overweight $\left(85^{\text {th }}\right.$ $95^{\text {th }}$ percentile) and $76(23.0 \%)$ were obese among the female participants in the private schools based on CDC classification for BMI. 
Prevalence of Overweight and Obesity among Secondary School Students in Ilorin Metropolis Kwara State, Nigeria

Table 8: Waist-to -Hip Ratio (WHR) of the Female Participants in the Secondary Schools

\begin{tabular}{|c|c|c|c|c|c|}
\hline $\begin{array}{l}\text { WH } \\
\mathbf{R}\end{array}$ & $\begin{array}{l}\text { Frequenc } \\
\text { y } \\
\text { Private }\end{array}$ & $\begin{array}{l}\text { Percentag } \\
\text { e }\end{array}$ & $\begin{array}{l}\text { WH } \\
\text { R }\end{array}$ & $\begin{array}{l}\text { Frequenc } \\
\mathbf{y} \\
\text { Public }\end{array}$ & $\begin{array}{l}\text { Percentag } \\
\text { e }\end{array}$ \\
\hline 0.66 & 1 & 0.4 & 0.70 & 26 & 7.5 \\
\hline 0.67 & 1 & 0.4 & 0.71 & 2 & 0.6 \\
\hline 0.71 & 1 & 0.4 & 0.74 & 2 & 0.6 \\
\hline 0.76 & 6 & 2.1 & 0.75 & 2 & 0.6 \\
\hline 0.77 & 8 & 2.8 & 0.76 & 6 & 1.7 \\
\hline 0.78 & 6 & 2.1 & 0.77 & 7 & 2.0 \\
\hline 0.79 & 4 & 1.4 & 0.78 & 6 & 1.7 \\
\hline 0.80 & 2 & 0.7 & 0.79 & 6 & 1.2 \\
\hline 0.81 & 24 & 8.5 & 0.80 & 4 & 2.3 \\
\hline 0.82 & 6 & 2.1 & 0.82 & 8 & 2.9 \\
\hline 0.83 & 3 & 1.1 & 0.83 & 10 & 2.3 \\
\hline 0.84 & 7 & 2.5 & 0.84 & 8 & 6.4 \\
\hline 0.85 & 14 & 5.0 & 0.85 & 33 & 9.5 \\
\hline 0.86 & 26 & 9.3 & 0.86 & 30 & 8.0 \\
\hline 0.87 & 26 & 9.3 & 0.87 & 19 & 5.5 \\
\hline 0.88 & 43 & 15.3 & 0.88 & 43 & 11.4 \\
\hline 0.89 & 49 & 17.4 & 0.89 & 52 & 13.0 \\
\hline 0.90 & 23 & 8.2 & 0.90 & 30 & 8.7 \\
\hline 0.92 & 3 & 1.1 & 0.91 & 23 & 6.6 \\
\hline 0.93 & 11 & 4.0 & 0.94 & 2 & 0.6 \\
\hline 0.94 & 5 & 1.8 & 0.95 & 5 & 1.4 \\
\hline 0.95 & 2 & 0.7 & 0.97 & 4 & 1.2 \\
\hline 0.96 & 1 & 0.4 & 0.99 & 4 & 1.2 \\
\hline
\end{tabular}




\begin{tabular}{llllll}
0.97 & 3 & 1.1 & 1.0 & 14 & 3.1 \\
0.99 & 2 & 0.7 & & & \\
1.0 & 4 & 1.4 & & & \\
Total & $\mathbf{2 8 1}$ & $\mathbf{1 0 0}$ & Total & $\mathbf{3 4 6}$ & $\mathbf{1 0 0}$ \\
\hline
\end{tabular}

The percentage analysis in table 8 shows that $3(1.2 \%)$ were underweight (WHR $\leq 0.75), 24(8.4 \%)$ had healthy WHR $(0.75-0.79), 82(29.2 \%)$ were at borderline waist-hip ratio $(0.80-$ $0.86)$ and $172(61.2 \%)$ were at the risk of abdominal fat (WHR $\geq 0.86$ ) among the female participants in the public secondary schools. In the same vein, $30(8.7 \%)$ were underweight, $27(7.2 \%)$ had healthy WHR, 93 (31.4\%) were at borderline and $196(52.6 \%)$ were at the risk of abdominal fat among the female participants in the private secondary schools in this study locale.

\section{Hypotheses Testing}

Hypothesis One: There is no significant difference between mean Body Mass Index of Male Students in the Private and Public Secondary Schools in Ilorin Metropolis.

Table 9: Showing t-test Analysis of Body Mass Index (BMI) of Male Students in the Private and Public Secondary Schools in Ilorin Metropolis

\begin{tabular}{lllllll}
\hline Variable N & Mean $\begin{array}{l}\text { St. } \\
\text { Dev. }\end{array}$ & Calc.t & Crit.t df & Decision \\
\hline
\end{tabular}

$\begin{array}{llllllll}\text { BMI } & 515 & 18.9 & 2.8 & 7.41 & 1.96 & 967 & \begin{array}{l}\text { Ho } \\ \text { Rejected }\end{array}\end{array}$

$\begin{array}{lll}454 & 20.3 & 3.1\end{array}$

\section{$\mathbf{P} \leq \mathbf{0 . 0 5}$}

The t-test analysis in the table 9 above revealed that the calculated $\mathrm{t}$-value of 7.41 is greater than the critical t- value of 1.96 and mean of 18.9 at the degree of freedom of $967(\infty)$ and 0.05 significance level. 
Prevalence of Overweight and Obesity among Secondary School Students in Ilorin Metropolis Kwara State, Nigeria

Therefore, the hypothesis which states that there is no significant difference between mean Body Mass Index of Male Students in the Private and Public Secondary Schools in Ilorin Metropolis is rejected. This means that significant different existed between the Body Mass Index of the two groups (Private and Public)

Hypothesis Two: There is no significant difference between means of Waist-Hip Ratio (WHR) of Male Students in the Private and Public Secondary Schools in Ilorin Metropolis.

Table 10: Showing t-test Analysis of Waist-to-Hip Ratio (WHR) of Male Students in the Private and Public Secondary Schools in Ilorin Metropolis.

\begin{tabular}{llllllll}
\hline Variable & N & Mean & $\begin{array}{l}\text { St. } \\
\text { Dev. }\end{array}$ & Calc.t & Crit.t & df & Decision \\
\hline WHR & 515 & 0.87 & 0.08 & 8.92 & 1.96 & 967 & $\begin{array}{l}\text { Ho } \\
\text { Rejected }\end{array}$ \\
& 454 & 0.76 & 0.24 & & & & \\
\hline
\end{tabular}

$\mathbf{P} \leq \mathbf{0 . 0 5}$

Table 10 reveals that the calculated t-value of 8.92 is greater than the critical value of 1.96 and mean of 0.87 at the degree of freedom of 967 and 0.05 alpha level. This implies that significant difference also existed between the mean WHR of Male Students in the Private and Public Secondary Schools in Ilorin Metropolis.

Hypothesis Three: There is no significant difference between mean Body Mass Index of Male Students in the Private and Public Secondary Schools in Ilorin Metropolis. 
Table 11: Showing t-test Analysis of Body Mass Index (BMI) of Female Students in the Private and Public Secondary Schools in Ilorin Metropolis.

\begin{tabular}{lllllll}
\hline Variable & N & $\square \pm$ SD & Calc.t & Crit.t & df & Decision \\
\hline BMI & 281 & $19.2 \pm 3.1$ & 2.83 & 1.96 & 625 & Ho \\
& & & & & & Rejected \\
& 346 & $18.7 \pm 3.2$ & & & & \\
\hline & $\mathbf{P} \leq$ & & & & & \\
& $\mathbf{0 . 0 5}$ & & & & &
\end{tabular}

Table 11 indicates that calculated t-value of 2.83 is greater than the critical value of 1.96 and mean of 19.2 at the degree of freedom of 625 at 0.05 significance level. Therefore, the hypothesis which states that there is no significant difference between mean Body Mass Index of Male Students in the Private and Public Secondary Schools in Ilorin Metropolis is rejected. This connotes that there is statistically significant difference between the mean BMI of female Students in Public and Private Secondary Schools in Ilorin metropolis.

Hypothesis Four: There is no significant difference between mean Waist-Hip Ratio (WHR) of Male Students in the Private and Public Secondary Schools in Ilorin Metropolis. 
Prevalence of Overweight and Obesity among Secondary School Students in Ilorin Metropolis Kwara State, Nigeria

Table 12: Showing t-test Analysis of Waist-to-Hip Ratio (WHR) of Female Students in the Private and Public Secondary Schools in Ilorin Metropolis.

\begin{tabular}{lllllll}
\hline Variable & $\mathbf{N}$ & $\square \pm$ SD & $\begin{array}{l}\text { Calc. } \\
\mathbf{t}\end{array}$ & Crit.t & $\mathbf{d f}$ & Decision \\
\hline WHR & 281 & $0.87 \pm 0.05$ & 4.8 & 1.96 & 625 & $\begin{array}{l}\text { Ho } \\
\text { Rejected }\end{array}$ \\
& 346 & $0.80 \pm 0.23$ & & & &
\end{tabular}

$\mathbf{P} \leq \mathbf{0 . 0 5}$

It can be deduced from table 12 that the calculated t-value of 4.8 is greater than the table value of 1.96 and mean of 0.87 at 625 degree of freedom and 0.05 level of significance. This indicates that significant difference existed between the mean Waist-Hip Ratio of the Female students in the Private and Public Students in Ilorin metropolis.

\section{Answer to Research Questions}

The four research questions were answered serially as they were stated earlier:

1. the percentage analysis revealed that $18.1 \%$ were overweight and $28.1 \%$ were obese based on BMI classification. The WHR analysis revealed that, $42.9 \%$ were at borderline while $0.4 \%$ was at risk of abdominal fat based on waist-hip ratio classification among the male participants in the public secondary schools.

2. among the male students in the private schools, the BMI analysis indicated that $42.1 \%$ were overweight and $20.1 \%$ were obese while classification based on waisthip ratio shows that, $36.1 \%$ were at borderline and $7.9 \%$ were at risk of abdominal fat among the male participants in the private schools. 
3. the percentage analysis also revealed that, $25.5 \%$ were overweight and $21.8 \%$ were obese among the female participants in the public secondary schools while waist-ration classification indicated that, $29.2 \%$ were at borderline and $61.2 \%$ were at risk of abdominal fat.

4. the BMI classification for female students in the private schools shows that, $28.6 \%$ were overweight and $23.0 \%$ were obese. The WHR classification also shows that, $36.1 \%$ were at borderline and $7.9 \%$ were at risk of abdominal fat respectively.

\section{Discussions}

This study investigated the prevalence of overweight and obesity among secondary school students in Ilorin metropolis. Four hypotheses were formulated for the study. Hypothesis one which stated that there is no significant difference between mean Body Mass Index(BMI) of male students in the Private and Public Secondary Schools in Ilorin Metropolis was rejected. The rejection of the hypothesis indicates that the Body Mass Index of the male students in the public and private differs and private students had higher BMI.

The percentage and frequency analysis of the BMI of the two categories also revealed that $4.2 \%$ were underweight, $49.6 \%$ had healthy weight, $18.1 \%$ were overweight and $28.1 \%$ were obese among the male students in the private schools, while $1.9 \%$ were underweight, $35.9 \%$ had healthy weight, $42.1 \%$ were overweight and $20.1 \%$ were obese among the participants in the public schools. Obesity and overweight was more prevalent among the private students $(28.1 \%)$. that if effective interventions are not provided; more students will be obese among the private schools students as more overweight was also recorded. Expectedly, more students were underweight (4.2\%) among the male students in the 
Prevalence of Overweight and Obesity among Secondary School Students in Ilorin Metropolis Kwara State, Nigeria

public school compared to their counterparts in the private $(1.9 \%)$ schools.

The difference in the overweight and obesity status could be linked to hypokinetic lifestyle of the male students attending the private schools such as increase in number hours for playing computer games, watching television, reduced physical movement to schools and probably disordered eating pattern (Ogunjimi, 2009; Wang \& Lobstein 2012; Ekpenyong \& Akpan, 2012). This finding was also corroborated by Akinlade, Afolabi, Oguntona and Agbonlahor (2012) who also reported a higher prevalence among the students in the private schools than in the public. Several studies that had been conducted revealed that pupils in the private high schools tend to be overweight than their public counterparts and this study is no deviation from the established claims. Ekpenyong and Akpan (2013) also recorded a higher prevalence among the boys in the private schools. The difference could be traceable to the improved socioeconomic status and changing pattern of life of parents and their wards which is more commonly observed among the adolescents in the private schools (Shebang, 2011).

The hypothesis two which stated that there is no significant difference between mean Body Mass Index (BMI) of female Students in the Private and Public Secondary Schools in Ilorin Metropolis was also rejected. A similar trend was observed between the females in the private and public secondary schools in Ilorin metropolis. This study found that $28.6 \%$ were overweight, $23.0 \%$ obese among the female students in the private schools, while, $25.5 \%$ were overweight and $21.80 \%$ were obese among the females in the public schools. Similarly, more students were underweight among the public students (10.1\%) than their counterparts in the private $(3.5 \%)$. 
Overweight and obesity was more prevalent among the female students in the private schools than their mates in the public. The observed difference could be traceable to the improved socioeconomic status of the parents of female students attending private schools which might have possibly influenced the lifestyle of the students leading to obesogenic behaviours such as reduced physical movement or lack of regular physical activities as majority of them go to school by cars, tricycle or motor bikes instead of walking, regular consumption of junks (ice-cream, burger, caffeinated soft drinks, chocolate candy and so on) while these practices are less common among the females in the public schools as most of them will have to walk some distance before getting to school, hawk goods for their parents in the street after school hours and act involvement in the domestic chores as observed by the researcher.

This finding is also supported by the report of Mustapha and Sanusi (2013) who recorded a higher prevalence among inschool female adolescents in the private schools with $7.4 \%$ overweight and 4.4\% obese. Ekpenyong and Akpan (2013) asserted that overweight and obesity is higher among girls residing in the urban areas and attending private schools. Ansa, Odigwe and Anah (2008) reported 4\% females as overweight and 3\% males obese respectively. However, the reported figures by the previous researchers were lower than the findings of this study as $28.1 \%$ of the males in the private schools were obese and $20.1 \%$ in the public schools, while, $23.0 \%$ were obese among the females in the private schools and $21.8 \%$ in the public schools. The findings is also in line with the report of Salazer \& Allen (2006) in which female students were more obese $(6.2 \%)$ compared to the male (4.2\%). A study in South Africa conducted among boys and girls in the high schools by Kruger and Macintyre (2006) also documented a higher prevalence among the girls. The reported 
Prevalence of Overweight and Obesity among Secondary School Students in Ilorin Metropolis Kwara State, Nigeria

higher prevalence among female in various studies indicated that in the near future, the female students will likely be more confronted with problem of overweight and obesity which will ultimately lead to cardiovascular diseases incidents than their counterparts in the public schools.

The hypothesis three which stated the there is no significant difference in the WHR of female students in the private and public was also rejected. The prevalence of abdominal obesity (visceral fat) among public and private secondary school students in Ilorin metropolis as indicated by percentage and mean values analysis and t-test statistics revealed that female in private schools were more at risk of abdominal fat with the mean WHR of 0.87 and this suggests that metabolic syndrome is likely to be rampant in the near future if left unchecked. The mean WHR of private and public female students were 0.80 and 0.76 respectively. This finding is also similar to that of Abah and Akpede (2012) who recorded a higher WHR among female adolescents in the private secondary schools in their study.

The findings of this study was further corroborated by the observations of Karayianis, Yanakoulia and Terzidou (2003), in which females had more weight. However, a higher percentage was observed across the two groups (male and female) in this study. Expectedly, a similar observations was made as seen in BMI of the two categories (public and private). The students in the private schools were more at risk of abdominal fat as indicated by the mean values. This finding is not too distant from that of Ojofeitimi and Sabageh (2013) who also recorded higher WHR among girls than boys. The difference in overweight and obesity pattern observed between male and female students indicated that in the future, there will be more obese female than male in the study locale if proper and adequate interventions are not given. 
The implications of the findings are that; more female students tend to be overweight and hence more predisposed to cardiovascular diseases risks, also, the students in the private schools are more at risk of obesity compared to the ones attending public schools. This observed overweight and obesity among the students could be traceable factors such as technological advancement, increased in production and availability of high calorie energy densed foods outlets, improved socioeconomic status of the parents, reduced or lack of physical exercise among others.

Hypothesis four which stated that there is no significant difference in the WHR of female students in the public and private secondary schools in Ilorin metropolis was also rejected. This connotes that there is significant difference in the WHR of the male in both categories with mean values of 0.87 and 0.76 in the private and public respectively. The values obtained among the male students in the public schools imply that they were within healthy WHR and they may likely not experience abdominal fat in their adulthood. The trend among the male in the private schools revealed a higher mean value $(0.87)$ which is suggestive of abdominal obesity in the near future if effective interventions are not provided.

\section{Conclusion}

Based on the findings of this study, the following inferences were drawn:

1. Male students in the private secondary schools in Ilorin Metropolis had higher prevalence of overweight and obesity compared to their counterparts in the public

2. Female students in the private secondary schools were at higher risk of abdominal fat than their public counterparts. 
Prevalence of Overweight and Obesity among Secondary School Students in Ilorin Metropolis Kwara State, Nigeria

3. The mean WHR and BMI were significantly high both in male and female students in Ilorin metropolis as determined by the mean values.

\section{Recommendations}

The study recommended based on the findings that;

1. Regular physical exercise should be given priority. This can be achieved by making physical education a compulsory subject at all levels of education in the secondary schools in Ilorin metropolis so that positive habits towards lifestyle of physical fitness and exercise can be developed.

2. There should be periodic assessment of students' overweight and obesity status using WHR and BMI methods in private and public secondary schools in Ilorin metropolis for proper monitoring and timely interventions.

3. There should be mass public enlightenment on the dangers of overweight and obesity. 


\section{References}

Abah, S .O, Aigbiremolen, A. O, Duru C.B, Awunor N.S, Asogun A.D, Enahoro F.O \& Akpede, M.E. (2012). Prevalence of overweight and obesity among students in private and public secondary schools in a peri-urban Nigerian town. Journal of Nutrition Health Food Science: 2(4): 1-5.

Akinpelu, A.O, Oyewole, O.O \& Oritogun K.S. (2012). Overweight and obesity: Does it

Ansa, V.O, Odigwe, C.O, \& Anah M.I.(2001). Profile of body mass index and obesity in Nigerian children and adolescents. Nigeria Journal of Medicine: 2008. AprJun;10 (2):78-80.

Akinlade, A.R, Afolabi W.A.O, Oguntona, E.B. \& Agbonlahor, M. (2012). Prevalence of

obesity among adolescents in senior secondary schools in Oyo, Nigeria. Journal of Health Food Science: 2(4):1-5.

CDC, 2010. CDC 2000 growth charts. Centers for Disease Contro

1. Available athttp://www.cdc.gov/growthcharts/cdc charts .htm. Retrieved on November 26,2017.Centers for Disease Control and Prevention (2000). Growth charts for the United States:

Dominic, O.L, Onifade, O.A. \& Olajide, E.O. (2010). Body Mass Index and the Waist/Hip Ratio among the female workers of Ilorin University, Nigeria. Medicina Sportiva. Journal of Romanian Sports Medicine Society: 7(4), 1467-1472.

Ekpenyong, C.E., \& Akpan, E.E., (2013).Urbanization Drift and Obesity Epidemic in Sub-Saharan Africa: A Review of Situation in Nigeria. European Journal of Sustainable Development. 2, 4, 141-164.

Hill, J.O. (2006). Understanding and addressing the epidemic of obesity: An energy balance perspective. Endocrine Reviews:27(7):750761.https://www.ncbi.nlm.nih.gov/pubm ed/1177354. Retrieved on December 6, 2017. 
Prevalence of Overweight and Obesity among Secondary School Students in Ilorin Metropolis Kwara State, Nigeria

improvements to the 1977 National Center for Health Statistics version. Available at

Karayiannis, D., Yannakoulia, M., Terzidou, M . (2003).

Prevalence of overweight and obesity in Greek school-aged children and adolescents. European Journal of Clinical Nutrition: 57:1189-1192.

Kelishadi, R. (2007). Childhood obesity in the eastern mediterranean region. In: R. K. Flamenbaum (Ed.), Global Dimensions of Childhood obesity New York, NY: NOVA Science Publishers.

Kruger, R. \& Macintyre, U.E. (2006). The determinants of overweight and obesity among10 -to-15 year -old schoolchildren in the North West Province, South Africa The THUSA BANA (Transition and Health during Urbanization of South Africans; BANA, children) Study. Public Health Nutrition. 2006; 9:351-358.

Lokuruka, M., (2013). A literature review of role of obesity in adult health with reference to Africa. African Journal of Food, Agriculture, Nutrition and Development. 13(1). 4356.

Monteiro, C. A, \& Conde, W.L., (2004). Obesity and inequities in health in the developing world. International Journal of Obesetics. 28: $1181-1186$.

Mustapha, R.A. \& Sanusi, R.A.(2013). Overweight and obesity among adolescents in Ondo State, Southwest, Nigeria. Africal Journal of Biomedical Research.16 (3). 205-210. occur in Nigerian adolescents in an urban community? International Journal of Biomedical and Health Sciences: 2008;4 (1):11-7.

National Health and Nutrition Examination Survey (2012). Prevalence of Overweight, Obesity, and Extreme Obesity Among Children: United States; the trends. Retrieved on December 15 , 2017availableat:https://www.cdc.gov/nchs/data/hestat/obesi ty_adult_09_10/obesity_adult_09_10.pdf 
Ochs-Balcom, H. (2006). Pulmonary function and abdominal adiposity in the general population. Chest. 129: 853-862.

Ogden, C. L., Carrol, M. D. \& Flegal, K. M. (2007). High body mass index for age among US children and adolescents, 2003 - 2006. American Journal of Medical Association. 299 (20), $2401-2405$.

Ojofeitimi, \& E.O. \& Sabageh, A.O.(2013). Obesity and Body image Discrepancy among

Park, K. (2010). Epidemiology of chronic non-communicable diseases and Conditions: Obesity.Park's Textbook of Preventive and Social Medicine: Banarsidas Bhanot: India Prem Nagar, Jabalpur press.

Reilly, J.J., (2006). Descriptive epidemiology and health consequences of childhood obesity Best Practice. Journal Clinical Endocrinology Metabolism., 19: 327-341.

Ruth, R.K., Russel, J. \& Debbie, A.L. (2008). Obesity in children part 1: Epidemiology, measurement, risk factors and screening. BMJ 2008; 337:a1824.

Salazar-Martinez, E.\&Allen, B. (2006). Overweight and obesity status among adolescents from Mexico and Egypt. American Medical Resource. 37: 535 -542.

Senf, J.H., Shisslak, C.M. \& Crago, M.A.(2006). Does dieting lead to weight gain? A four-year longitudinal study of middle school girls in sub-Saharan Africa: A Review of Situation in Nigeria. European Journal of Sustainable Development. 2, (4), 141-164. Waist/Hip Ratio among the female workers of Ilorin University, Nigeria.

Wang, Y. \& Lobstein, T. W. ( 2012). Worldwide trends in Childhood Overweight and Obesity. International Journal of Paediatric Obesity. 1:11-25.

WorldHealthOrganisation(2016).Facts about overweight and Obesi ty. Available athttp://www.who.int/mediacentre/factsheets/f s311/en/Retrieved on November 6, 2017 . 